Article

\title{
Sustainability Governance Mechanisms in Supply Chains: An Application in the Retail Sector
}

\author{
Jesús Morcillo-Bellido *(1) and Alfonso Duran-Heras $(\mathbb{D}$ \\ Escuela Politécnica Superior, Área de Ingeniería de Organización, Universidad Carlos III de Madrid, \\ Avenida de la Universidad, 30, Leganés, 28911 Madrid, Spain; duran@ing.uc3m.es \\ * Correspondence: morcillo@ing.uc3m.es; Tel.: +34-91-6248765
}

Received: 29 July 2020; Accepted: 18 August 2020; Published: 25 August 2020

\begin{abstract}
This study analyzes supply chain sustainability governance mechanisms, and their characterization, typology, adoption and relationship with the overall level of sustainability in the supply chain, and with the adopting firm's competitive strategy. It is a case-based study conducted in the Spanish retail sector. A representative set of mechanisms is identified, and both their theoretical background and their degree of practical adoption is established. These mechanisms are then characterized in terms of several traits regarding either the mechanisms themselves or the way they are adopted both by the focal company (internal view) and by its suppliers (external view) in each of the cases. Results suggest that mechanisms might be classified into either 'enablers', which increasingly constitute a prerequisite for achieving acceptable levels of sustainability, and 'differentiators', which can potentially confer sustainable strategic advantages. Actually, achieving these advantages, however, seems contingent on the additional attainment of a comprehensive 'depth' in the implementation of an integrated set of mechanisms of both types, both internally within the focal company and throughout the whole supply chain, as measured by the traits proposed in the study. Furthermore, the concept of 'circular improvement models' for sustainable supply chains, akin to Total Quality Management models, is proposed by the authors. The resulting model encompassing enabling and differentiating governance mechanisms could guide the self-evaluation and improvement plans of companies aiming to improve their supply chains sustainability; further guidance on 'deep adoption' comprehensive strategies and on the potential for self-reinforcing continuous improvement in sustainability beyond a certain threshold are provided by the study's conclusions.
\end{abstract}

Keywords: sustainability; retail; supply chain; sustainability governance mechanists; retail sustainability

\section{Introduction}

The competitiveness of a company reflects its ability to overcome in the long term its current and future competitors within a certain industry's environment. A company must know how to constantly generate 'sustainable value' through a certain strategy that allows it to achieve its long-term objectives [1]. Porter [2] established that the company's strategy represents the activities of the organization that fit and create added value. For other authors, such as Barney and Hesterly [3], strategy is the way to create competitive advantages, maintained over time. The emphasis on the long term is very significant, since sustainability implies continuity, thus achieving a 'sustainable' competitive advantage requires being able to apply certain long-term policies that lead to outperforming the competition. For some authors, such as Starik and Rands (1995) [4], sustainability is related to the ability of one or more organizations, either individually or collectively, to survive and reach long-term leadership positions. In Shrivastava's [5] opinion, sustainability could be considered from an environmental angle; it is related to the management of Total Quality, with a specific environmental focus. Sustainability could be defined as the ability to run businesses that achieve long-term objectives 
of economic, environmental and social improvement [6-9]. For Lozano [10], the sustainability of an organization can be defined as those activities that proactively contribute to a sustainable balance, encompassing economic, environmental and social aspects.

Since, conceptually, sustainability derives from the very broad concept of sustainable development, it has sometimes been considered as a parallel construction to corporate social responsibility [11]. According to these authors, the development of sustainability practices stems from the pressure exerted from different sides, from government norms and social pressure as well as from the development of new competitive advantages through the application of business practices that are considered sustainability generators. Some of these practices could be considered to be superficial and do not necessarily imply real conviction about their effectiveness by the companies that apply them. Several authors consider that some organizations are still not very receptive to 'sustainability' practices that rest on company's voluntariness, if they are not legally enforced [7]. Therefore, their practices would essentially be an adaptation of legal norms or recommendations, aimed at being recognized as 'politically correct' in the environment in which they carry out their business, rather than the result of a real conviction that these practices lead to a clear improvement in the company's competitiveness. In the opinion of the authors of this paper, sustainability could lead to important competitive advantages, but only when it goes beyond mere compliance to current laws and legal norms, since this, being commonplace, does not generate differentiation.

Over the last two decades, driven by the raised awareness of environmental, social and economic issues, the concept of sustainability has reached a high level of dissemination and interest within organizations, and this has been transferred to their supply chains [12]. Having aroused great interest in recent years, both among academics and executives, research on the impact of sustainability in supply chains has become a top priority [13]. Since it was introduced in the early eighties of the last century, the concept of a supply chain has been used to describe the planning, control of materials and information flows between companies that collaborate in the processes that enables the delivery of goods and services promised to customers [14]. As Chopra and Meindl [15] indicate, the supply chain is conceived of as the group of entities involved in the fulfillment of an agreed commitment to a customer, both in goods and services. Within this definition, it is necessary to emphasize that more than one entity is involved in the process of deciding and executing the promise to the customer, managing resources, information and processes without being entirely under the total control of a single organization. However, there is usually a company that leads the supply chain, which we will refer to as the 'focal company'. Sustainability and supply chains are two concepts that have created many research studies and debates in the last twenty years [16]. The increasing adoption of sustainability practices in the supply chain highlights their interdependence [17]. Researchers have studied issues such as the impact and implications of sustainability in the different organizational processes [13], and their consequences in supply chain management (SCM). Over time, research in SCM has been expanded and focused on issues such as supply chain risk management [18], the analysis of certain behavioral indicators [7], relations established within the supply chain [19], integration between supply chain members [20], conflicts within the network that forms the supply chain [19], and the governance of the supply chain [21].

According to Seuring and Müller [16], sustainable supply chain management (SSCM) could be defined as "the management of material, information and capital flows, as well as cooperation among companies, along the supply chain while taking goals from all three dimensions of sustainable development (economic, environmental and social) into account which are derived from customer and stakeholder's requirements". On the other hand, Carter and Rogers [6] define SSCM as "the strategic, transparent integration and achievement of an organization's social, environmental and economic goals in the systematic coordination of key inter-organizational business processes for improving the long term economic performance of the individual company and its supply chain". In the definitions of SSCM, the management of internal and external relations is deemed a top priority. The proper management of these relationships leads to the creation of value, the increase in efficiency and, as a 
whole, the improvement of a supply chain's global result; all of this takes place in a 'sustainable' way. Authors such as Ahi and Searcy [22] argue that SSCM is essentially a logical and natural extension of the traditional SCM vision, expanding it to other issues that are key in the company strategy; they identify seven aspects that should be included in order for a supply chain to be considered sustainable (economic, environmental, social, voluntariness, long-term vision, resilience and involving stakeholders).

Consequently, a certain level of sustainability could be achieved over time by placing a stronger focus on what is happening in the supply chain and visualizing the whole supply chain as a key process that not only goes through the organization itself, but also extends to the rest of the supply chain's constituents. Authors such as Hassini et al. [7] have identified some aspects that are not yet sufficiently studied within the SSCM, such as the need to deepen the 'theoretical research' to develop principles or foundations that could take into account the particularities of the different supply chains. The initial studies published on SSCM highlight the importance of collaborative relationships [23] and the formalization of different sustainability governance mechanisms [24]. Given the relevance of this topic, some research on SSCM [25] is starting to focus on the role played by the governance mechanisms within the SSCM. Carter and Easton [26] suggest that a better understanding is needed regarding how the tools or governance factors of the supply chain are affecting sustainability strategies, particularly in matters related to contractual and non-contractual relationships. However, several aspects of the SSCM are still poorly studied; for example, Kovács [27] insists on the need to examine environmental and social responsibilities beyond the limits of the organizations themselves, emphasizing the need to understand the implications of these practices throughout the whole supply chain, both upstream and downstream, from suppliers to end consumers.

Although research has provided different frameworks of reference $[23,28,29]$ to investigate the relationship between the supply chains' sustainability governance mechanisms and the results in sustainability, there is only limited evidence on how the strategies and business models developed to improve the sustainability of companies are effectively translated into practices aligned with the organization's strategy, as well as on their influence on the company results. Authors such as Carter and Easton [26], Petschow [30], Husted and Sousa-Filho [31] and Du Plessis et al. [32] suggest that a better understanding of how the governance mechanisms of supply chain sustainability affect the SCS's own strategies is needed.

This mixture of perceived importance and relevance, combined with limited evidence, especially of the type that companies could effectively use while setting their course for the deployment of effective supply chain sustainability governance mechanisms, particularly in the retail sector, constitutes the backdrop for the design of this study. It led its authors to consider that an in-depth, case-based analysis of how the leading companies in the dynamic and innovative Spanish food retail sector were actually applying these mechanisms would reveal novel, valuable, actionable insights. Thus, a decision was taken to harvest the theoretical underpinnings developed in the recent research streams and combine them into an applicable model that could then be benchmarked against the actual practices being implemented by these leading companies. Within the general objective of improving our understanding of the overall workings of the SC sustainability governance mechanisms, more specific aims included: (i) shedding light on whether companies actually developed sustainability governance mechanisms within their supply chains; (ii) characterizing the types of mechanisms being developed, as well as their implementation; and (iii) tentatively exploring eventual causal relationships between the implementation of such mechanisms and the integrated sustainability level achieved by those organizations.

\section{Supply Chain Governance Mechanisms}

Governance is considered to be the structure that ensures that decisions are made along the lines determined by the organization's corporate strategy, in order to increase or maintain the value of the company in the long term [33]. Authors such as Pilbeam et al. [21] highlight the clear opportunity for academics to carry out studies to clarify the relationship between the governance mechanisms for 
supply chain sustainability and their results. Based on Giménez and Sierra [34], it could be emphasized that the mechanisms that make up a sustainable supply chain encompass the practices, initiatives and processes used by the focal company (the company that acts as the supply chain leader) to manage its relationships both between its internal processes and with the other supply chain members and stakeholders, in order to implement its sustainability strategy throughout the whole chain.

The published studies basically highlight three dimensions of governance mechanisms in supply chains: collaboration, formalization, and direct or indirect mechanisms. Thus, some authors [35] consider that companies can implement their sustainability strategies either by means of their power in the market, through non-collaborative relationships, or adopt a collaborative governance style that bases decisions on a shared consensus with the other supply chain members. In a non-collaborative environment, the focal company imposes its rules through the supplier contracts by using its negotiation power, so that its decisions are merely conveyed to the other supply chain members in order to be implemented, or applied within contractual, signed agreements.

According to Hingley [36], in the case of SSCM, evidence could be found, as confirmed by other authors [34,37], suggesting that the governance of a sustainable supply chain is generally based on mechanisms where mutual collaboration prevails among its members. Usually, this consensual approach facilitates the implementation of sustainable practices, since it generates a higher interest in result collaboration than when the practices are carried out only because they are imposed by the focal company.

Formalization is another dimension suggested in the literature characterizing the mechanisms of governance of supply chains that could be considered sustainable [21,24]. It can be defined as a trait whereby the decision process is regulated by explicit rules and procedures recognized and applied by the supply chain members. Formal mechanisms include: (i) control and reporting systems, through which organizational structures can handle incentives; (ii) operational procedures established along the supply chain; and (iii) procedures focused on the resolution of potential conflicts. Informal mechanisms are characterized by being based on personal relationships, rather than formally instituted organizational structures and procedures. These informal mechanisms are particularly contingent on the culture within which the company manages its operations; they have, however, a high component of instability that is related to the social environment and the specific people who work in a certain organization. All this could lead to the identification of a typology of governance mechanisms, distinguishing between those that we consider formal and those that could be considered as informal coordination mechanisms.

Recently, some authors identified in their research $[38,39]$ a group of mechanisms characterized by being based on the comprehensive recollection of information in order to assess the environmental and social supplier performance, and their compliance with codes of conduct previously established by the focal company as sustainability standards $[40,41]$. These mechanisms have been termed in the literature as 'supplier assessment'. Other studies are focused on mechanisms such as communication, knowledge sharing, training and support provided by the focal company to improve the capabilities of its suppliers with respect to environmental, social and economic objectives; these mechanisms have been referred to in the literature as 'supplier collaboration' [12,31,42]. Still another group of mechanisms adopted by the focal companies has been identified by other authors [43]; they are based on collaboration with other organizations, academia and government to share and implement practices that improve supply chain sustainability; this group is referred to as a 'multi-stakeholder initiative' mechanism.

From this categorization, the mechanisms have been grouped into direct and indirect [34,39]. Direct mechanisms are those in which the focal company invests time and relevance resources in the management of supplier relationships [44], while indirect mechanisms are based on third-party standards and do not require the focal company to invest time and resources in directly managing sustainability improvements by other supply chain members [45]. Authors such as Koberg and Longoni [39] present the governance mechanisms as detailed in Table 1. 
Table 1. Governance mechanists. Source: based on Koberg and Longoni (2019).

\begin{tabular}{cc}
\hline Direct Mechanisms & Indirect Mechanisms \\
\hline Supplier assessment. Codes of conduct and standards & Third party-specific certification \\
Supplier collaboration (training, financial support) & Third party multi-industry certifications \\
Multi-stake holder initiative (e.g., roundtable for & (e.g., ISO 14000 family) \\
Sustainable Palm Oil) & \\
\hline
\end{tabular}

These authors conclude that, among the mechanisms that they call 'direct', the topics related to 'supplier assessment' and 'supplier collaboration' have been subject to a more thorough study, while those related to the 'multi-stakeholder mechanisms' mechanism have received less attention. Some studies have proposed that the participation of the focal company in multi-stakeholder initiatives could improve the collaboration issue and the adoption of higher level practices on environmental and social areas [46]. Regarding indirect mechanisms, there is a remarkable level of agreement in the literature in accepting that the mere fact of having standards does not lead, by itself, to a better level of sustainability in a given supply chain. This is particularly applicable to voluntary standards (e.g., the ISO 14000 family), which have sometimes been questioned [47] since some companies might try to merely comply with certain formal norms, without internalizing in their own culture the strategic relevance of sustainability.

\section{Objective and Study Methodology}

The state of the art review of supply chain governance mechanisms carried out in the previous section enabled the authors to further develop the aims set out in the introduction, and consequently to choose an appropriate methodology for achieving them. Within the abovementioned context of perceived importance and relevance backed by limited usable evidence, and the overarching objective of furthering existing knowledge on the role, functioning and implications of SC sustainability governance mechanisms in retail, the following objectives were defined:

- Establish the relationship between the published literature and the actual utilization of such mechanisms by leading retailers. This entails nailing down the various published approaches into a practicable list of mechanisms, whose utilization (or lack thereof) by each specific company could be asserted, and actually evaluating their degree of adoption. Furthermore, it involves investigating whether actual practice suggests the existence of additional mechanisms or variants therefrom that have so far been insufficiently investigated.

- Characterize the actual implementation of these mechanisms (at the mechanism/company level). The literature review revealed a substantial gap involving the detailed analysis of how companies actually implemented the mechanism they used. As is particularly relevant for SC analysis, most published studies restrict this analysis to the focal company. Thus, a decision was taken to characterize each mechanism used by each company through the 'Internal vs. External' trait whether its implementation was supply-chain wide. Additional traits, such as Collaborative/Non-Collaborative and Formal/Informal would allow the detailed characterization of that implementation. Furthermore, mechanism-level traits, such as whether a given mechanism is Direct or Indirect, would be established.

- Tentatively explore the eventual causal relationships between the implementation of such mechanisms and the integrated sustainability level achieved by those organizations, with particular focus on their potential to create differentiation/competitive advantages.

Regarding the choice of an appropriate methodology for achieving these objectives, it is worth noting the study carried out by Hassini et al. [7], where the authors reviewed the published literature on supply chain sustainability, concluding that most of the published papers are mainly analytical models related to topics such as facility location, scheduling, supplier selection and simulations. According 
to this study, among these papers, the case study was the second most frequently used method. This contrasts somewhat with the slightly skeptical attitude to case studies as reliable research tools found in other areas. Perhaps this might be attributable to the fact that sustainability is a relatively new research field. Thus, researchers still need to broaden their understanding of the situations described in real cases in order to deepen the knowledge of what is happening and comprehend better the factors involved prior to proposing any theory, this is something that can be achieved through case studies [48].

Thus, given the nature of the topics to be investigated, we decided to carry out a case-based study. This is a method that, according to Eisenhardt [49], is suitable for issues that have to do with strategic business management decisions. Yin [50] advises using a case study where the boundaries between the context and the phenomenon to be observed are not evident.

As for the choice of the actual cases to be analyzed, as justified in the introduction, the authors opted for an inductive, in-depth analysis of the four leading companies operating nation-wide in the dynamic and innovative Spanish food retail sector. Table 2, below, summarizes the main characteristics of companies included in the study, where the column 'Products' indicates the product range and the columns 'Type' and 'Legal Structure' show the company's legal structure and the business focus (local/multinational). The last column represents the supply chain structure (local and/or international).

Table 2. Company characteristics. Source: authors' elaboration.

\begin{tabular}{ccccc}
\hline Company & Products & Type & Legal Structure & Supply Chain \\
\hline A & Food & Local & Family owned & Local mainly \\
B & Food/apparel & Multinacional & Large multinational & Local/intern. \\
C & Food & Local & Local/public & Local mainly \\
D & Food/apparel & Local & Local/family owned & Local/intern \\
\hline
\end{tabular}

All four companies belong to the top 10 overall retail (not merely food) Spanish ranking, and, taken together, they account for over $40 \%$ of Spanish food retail. They are referred to in this article as companies A, B, C and D.

One additional reason for choosing the Spanish food retail sector was the feasibility of the author's access to company executives if and where they were required to conduct interviews.

Information was recollected using secondary data and published documents, such as official company reports, financial reports and conference information, etc. As detailed in the following section, the initial aim of this analysis was to combine the theoretical frameworks developed in the recent research streams with the in-depth analysis of the company's practices, in order to distill a workable list of mechanisms upon which to base this analysis.

On top of that, in-depth interviews with executives of companies A and D were performed in order to check certain pre-conclusions, using semi-structured questionnaires that, having a defined scheme, allowed the collection of relevant aspects.

The resulting mechanism list is presented in Section 4.2 (Case Study Analysis), mechanisms I to VIII. For each of them, the relevant bibliographical references from which their theoretical underpinnings were derived are listed there. Besides these mechanism-specific references, for the six 'Direct' mechanisms, references $[34,39,44,46]$ also provide more generic foundations.

An additional aim of this analysis involves investigating the existence of additional mechanisms or variants; mechanisms IX and X in Section 4.2 fall into this category.

The resulting list of 10 mechanisms was then benchmarked against the actual practices being implemented by these four companies, and their implementation, characterized as described above. Finally, eventual causal relationships with the overall sustainability level achieved were explored. 


\section{Sustainability Governance Mechanisms in the Spanish Retail Sector}

\subsection{The Sector and Companies' Backgrounds}

Regarding the retail sector, the increase in both regulation and consumer requirements regarding sustainability has exerted pressure on companies to work on the implementation of environmental corporate strategies on the products and services they offer [51]. Jones et al. [52] define retailers as the active intermediaries between the producers of primary materials, manufacturers and consumers, which have a broad capacity to influence supply chain sustainability. Retailers could have a great impact on sustainability, considering both their direct impact on their own operations $[53,54]$ and the implication on the overall supply chain activities from raw materials to industrial process and final consumption [55]. However, the role that retailers must play in the governance of sustainability along the supply chain shows ample opportunities for academic research, because they are not sufficiently studied yet [56,57]. A study by Naidoo and Gasparatos [58] delved deeply into the identification of the factors that should be considered in the implementation of corporate strategies for environmental sustainability within the retail sector and tried to establish some measurement ratios.

Most of the published studies deal with the environmental impact of certain retailers and their supply chains [59,60]; other studies have tried to study the environmental benefits of mitigation strategies applied in the sector [61-63]. In general, these studies focused on the significant environmental impact of the retail sector, rather than on an integral vision of its sustainability. Therefore, retailers are continuously increasing the implementation of so-called Corporate Environmental Sustainability (CES) strategies in order to increase their level of environmental sustainability, based on three drivers: to improve their profitability, and to comply with environmental standards and stakeholder pressure [58].

Regarding the analyzed companies, they are part of the top retail companies operating in Spain, and among them account for over $40 \%$ of the Spanish food market. Their businesses are focused on different ranges of products and services (food, household products, fashion and other domestic services), and they are mainly focused on final consumers and family business (B2C); only a small share of their businesses is dedicated to business to business (B2B).

Company A is one of the leading companies in Spain in the retail sector. It is a family company; the vast majority of whose activities are in Spain. For years, it was focused on improving sustainability practices and achieving the goal of managing a sustainable supply chain. Since its foundation, company A has worked on internal improvements to subsequently extend these practices to a select group of top-level suppliers (Tier-1). These suppliers deal with an extensive industrial network to manufacture distribution-brand products exclusively for company A, under long term agreements usually encompassing a five to ten-year timeframe. These suppliers diligently apply the sustainability practices that the focal company develops and initially tests in its own processes, so that each of these top suppliers of the supply chain tends to apply as 'mirror policies' those that have been applied previously by the focal company.

Its management strategy is based on the continuous improvement of its supply chain process. For instance, it avoids opportunistic negotiations with its key suppliers to achieve lower prices in the short term that could jeopardize future improvements on price and/or quality. Company A bases its price negotiation scheme on the long-term management pressure of suppliers' efficiency. Some years ago, it developed a plan to extend sustainability practices to suppliers of the raw materials and basic supplies required for the manufacturing of products sold under its own 'distributor brand'. Thus, in its 'sustainable supply chain', it tries to integrate into an integral supply chain approach its upstream suppliers, such as the farmers who produce meat or wheat as inputs to the sausage or cookie manufacturers' supply chains.

Company B is a multinational company based in another European country, which has developed its activities in Spain since the middle of the twentieth century. It belongs to a multinational network that operates in dozens of countries in food and apparel products for households. The company 
applies locally the practices that are developed by the headquarters on its home market. Their use is mandatory. This company works on extending supply chain practices based on standardized and common standards and procedures in all countries. These norms emanate from the general policy (standards) elaborated at the headquarters. Its supply chain management strategy follows practices that might be considered to be traditional, regarding supplier relationship and sustainability practices. It complies with all the legal norms and tries to develop sustainability practices that can be considered as such. However due to its global purchasing policy and supplier management policy, that is heavily skewed towards lowering purchasing prices (probably without taking into account the total cost of ownership), the company distributes in the Spanish market several consumer products, such as dairy food, that are transported from remote sources. This does not contribute positively to the overall environmental sustainability of company B's supply chain. In addition, observed collaborative practices with suppliers in their supply chain cannot be described as a reference for good practices, in terms of a comprehensive vision of the supply chain. They generally tend to seek negotiations based more on short-term agreements than on relationship building that could contribute to improving the supply chain's long-term competitiveness through supply chain process improvement.

Company $\mathrm{C}$ is a Spanish-based company, with only small business operations abroad, which is solely focused on food products trading in their store network and with a high percentage of business based on its own 'distributor brand' range. Its business is characterized by a reduced range of items, sold mainly under their own distribution brand. The company's business is based on a network of small, mostly franchised, neighborhood stores, and Company $\mathrm{C}$ also manages the distribution and delivery of food products sold by large online platforms, especially covering fresh products' last mile delivery. This company has a relationship model with its suppliers that looks very similar to company $\mathrm{B}$, based primarily on timely negotiation order by order, or for a short time period, always looking for the lowest possible prices.

Company D is a large Spanish distribution company with a century of experience, and is very oriented to the department store model, where consumers can find almost any good or service they may need. It is characterized by a large range of goods and services, including food, textiles and many others related to the customer home and leisure supplies. Its supply chain is organized in a very traditional way and supplier relations follows a common traditional model, with periodic price negotiations and without either agreements to improve the supply chain or a processes integration vision. In recent years, due to the economic difficulties in the retail sector, the pressure on the cost/price negotiation has increased.

\subsection{Case Study Analysis}

This study focuses on the supply chain sustainability governance mechanisms used by these companies. As shown in Table 3, ten major mechanisms have been identified and characterized. As described in the methodology section, most of these mechanisms (I-VIII) derive from the literature review described in the 'supply chain sustainability governance mechanisms' section above; the specifically applicable bibliographical references for each of them is listed within its description. This initial group is complemented by others (IX-X) that stem from the study itself, through the in-depth analysis carried out of the sustainability governance practices being applied. These additional mechanisms may be sector-specific, or might even have been developed ad hoc by one of the companies being reviewed. These mechanisms have been characterized trough the traits discussed in the literature review, such as direct vs. indirect, formal vs. informal and collaborative vs. non-collaborative. However, while the scope in most published studies is restricted to the focal company, this paper provides two complementary views that the authors consider to be an additional contribution of this research to the knowledge: (i) the focal company vision (the 'Internal view', denoted by an 'Int' in Table 3) and the rest of the supply chain members' view (Tier 1 suppliers, the 'External view', denoted by an 'Ext'). 
Table 3. Characterization of supply chain sustainability governance mechanisms in the case studies. Source: own elaboration.

\begin{tabular}{|c|c|c|c|c|c|c|c|c|c|c|c|c|}
\hline \multirow{3}{*}{$\begin{array}{c}\text { Mechanisms } \\
\text { I. Sustainability report (D) }\end{array}$} & \multicolumn{3}{|c|}{ Company A } & \multicolumn{3}{|c|}{ Company B } & \multicolumn{3}{|c|}{ Company C } & \multicolumn{3}{|c|}{ Company D } \\
\hline & \multirow{2}{*}{$\begin{array}{c}\text { Int } \\
F\end{array}$} & \multicolumn{2}{|c|}{ Ext } & \multirow{2}{*}{$\frac{\text { Int }}{\mathrm{F}}$} & \multicolumn{2}{|c|}{ Ext } & \multirow{2}{*}{$\frac{\text { Int }}{\mathrm{F}}$} & \multicolumn{2}{|c|}{ Ext } & \multirow{2}{*}{ Int } & \multicolumn{2}{|c|}{ Ext } \\
\hline & & $\mathrm{F}$ & $\mathrm{C}$ & & $\mathrm{F}$ & NC & & - & - & & - & - \\
\hline II. Sustainable SC certification (ID) & $\mathrm{F}$ & $\mathrm{F}$ & $\mathrm{C}$ & $\mathrm{F}$ & - & - & - & - & - & $\mathrm{F}$ & - & - \\
\hline III. Sustainability Committee (D) & $\mathrm{F}$ & $\mathrm{F}$ & $\mathrm{C}$ & $\mathrm{F}$ & - & - & - & - & - & - & - & - \\
\hline IV. Supplier evaluation program (D) & $\mathrm{F}$ & $\mathrm{F}$ & $\mathrm{C}$ & $\mathrm{F}$ & & - & - & - & _- & $\mathrm{F}$ & _- & - \\
\hline $\begin{array}{l}\text { V. Environmental certifications } \\
\text { (e.g., ISO 14001) (ID) }\end{array}$ & $\mathrm{F}$ & $\mathrm{F}$ & NC & $\mathrm{F}$ & $\mathrm{F}$ & NC & F & $\mathrm{F}$ & $\mathrm{NC}$ & $\mathrm{F}$ & $\mathrm{F}$ & $\mathrm{NC}$ \\
\hline VI. Strategic SSCM plans (D) & $\mathrm{F}$ & $\mathrm{F}$ & $\mathrm{C}$ & $\mathrm{F}$ & - & - & - & - & - & - & - & - \\
\hline VII. Local suppliers/sourcing (D) & $\mathrm{F}$ & $\mathrm{F}$ & $\mathrm{C}$ & $\mathrm{F}$ & Inf & $\mathrm{NC}$ & Inf & - & - & Inf & - & - \\
\hline VIII. Waste reduction program (D) & $\mathrm{F}$ & $\mathrm{F}$ & $\mathrm{C}$ & $\mathrm{F}$ & Inf & NC & - & - & - & $\mathrm{F}$ & Inf & $\mathrm{NC}$ \\
\hline $\begin{array}{c}\text { IX. Sustainability innovation } \\
\text { committee (D) }\end{array}$ & $\mathrm{F}$ & F & $\mathrm{C}$ & - & - & - & - & - & - & - & - & - \\
\hline $\begin{array}{l}X . \text { Long term supplier development } \\
\text { program (D) }\end{array}$ & $\mathrm{F}$ & $\mathrm{F}$ & $\mathrm{C}$ & - & - & - & - & - & - & - & - & - \\
\hline Number of mechanisms found & 10 & 10 & 10 & 8 & 4 & 4 & 3 & 1 & 1 & 6 & 2 & 2 \\
\hline
\end{tabular}

Note: C: Collaborative/NC: Non-Collaborative; F: Formal/Inf: Informal; -: not applied or no data. Mechanisms: D: Direct/ID: Indirect.

In order to illustrate how the various companies analyzed follow distinct sustainability governance strategies, each mechanism will now be discussed in turn:

I. Sustainability report. (Bibliographical references that provide the theoretical background, see Methodology: [21,24]) All of the companies analyzed here compile their Sustainability Reports and publish them through various channels (Annual Reports, web). Therefore, this formal mechanism is found in all four cases; however, its characterization reveals substantial differences in how they apply it. Company A developed this mechanism both internally and throughout its supply chain, through close cooperation between the focal company and its suppliers. Company B, meanwhile, also extends this mechanism to its suppliers; however, it does not cooperate with them for its implementation. Companies $\mathrm{C}$ and $\mathrm{D}$ apply this mechanism solely in the focal company, and do not promote its adoption by their suppliers; if any of them submits Sustainability Reports, they do it of their own free will.

II. Sustainable SC certification $[34,39,45,47]$. Three out of the four focal companies resort to various types of Sustainable SC certification schemes, such as Roundtable on Sustainable Oil (RSPO) on palm oil, the International Sustainability Carbon (ISC) certification of circular and bio-based approaches or SCS Certified Green Products (an indirect mechanism). Only company A, however, extended this approach to its major suppliers as a 'must have'; besides this, it cooperated with them in order to simplify and streamline its implementation. Companies B and D have only applied it internally, leaving it up to their suppliers whether to adopt it or not. No evidence was found of its application by company C.

III. Sustainability committee $[21,24]$. Companies A and B created a 'Sustainability committee' in charge of the planning and monitoring of sustainability improvement practices. In both companies, it is a formal mechanism, but only in company A's supply chain is it formally applied by the Tier 1 suppliers, with collaborative support from the focal company.

IV. Supplier evaluation program [38-41]. Companies A, B and D engage in systematic evaluation of the performance of the sustainability practices of their Tier 1 suppliers. Only company A extends this approach to their main suppliers, whereby they, with collaborative support from the focal company, in turn systematically evaluate the sustainability practices of their own (Tier 2) suppliers. No data has been found in company $\mathrm{C}$ suggesting the presence of an equivalent mechanism.

V. Environmental certifications $[34,39,45,47]$. This indirect mechanism relies on environmental standards, such as the ISO 14001. Specialized 'certification' organizations, or 'registrars', can be contracted to review a company's Environmental Management System and eventually certify, or 'register', its compliance with the standard (self-declaration of conformance is also an option; however, it carries less weight). All four companies have implemented this mechanism both in the focal company and in their main suppliers, in a formal, non-cooperative way. 
VI. Strategic SSCM plans [12,31,42,43]. In companies A and B, a formally established steering group strategically manages their SC sustainability improvement initiatives to ensure smooth progress towards achieving an SSC. Nevertheless, only company A showed evidence of simultaneously proactively developing long term joint sustainability development strategies with its major suppliers.

VII. Local suppliers/sourcing [12,31,42,43]. The promotion of local sourcing through the development of local suppliers is widely considered to be instrumental in the sustainability and competitiveness of supply chains, since it substantially improves product flows, particularly for perishable food products. Companies $\mathrm{A}$ and $\mathrm{B}$ have formalized this approach in the focal company, while companies $C$ and $D$ apply it in the focal company in an informal, non-encompassing manner, leaving out some geographical centers and product ranges. Company A extends this approach in a formal and cooperative fashion through its SC, while company B does it in an informal, non-cooperative manner.

VIII. Waste reduction program [12,31,42,43]. All of the companies, bar C, have developed specific plans and objectives to reduce waste, understood in its most general sense (product deterioration, obsolescence, idle time and any other value losses). They all apply the mechanism in the focal company formally. Its 'external characterization', however, reveals that, while company A applies it in a formal and cooperative way in its supply chain, company B resorts to an informal, non-cooperative approach.

It is worth highlighting that company A, besides applying supply chain sustainability governance mechanisms also employed by other companies, has internally developed specific, complementary mechanisms:

IX. Sustainability innovation committee. A platform for the 'design of innovative sustainability practices', composed of 23 key SC suppliers. It could be considered a 'Sustainability practices innovation committee', focused on improving the processes of the main SC suppliers, particularly those who manufacture their own distributor brands. It constitutes a 'sustainable innovation' mechanism within company A's SC, aimed at: (a) improving process efficiency in both the focal company and its key suppliers, (b) fostering strategic process innovation throughout the SC, and (c) prioritizing projects promoting food safety.

$X$. Long term supplier development program. A program focusing on the long term development of a stable supplier base, capable of guaranteeing the supply of a set of brands (generally, distributor brands) with consistently high quality at a competitive cost. As an illustration, this program led to the development of a specialized exclusive supplier that became the absolute market leader in dermatological and personal care creams. This program encourages long term collaborative relationships, transcending the periodic negotiation of sale terms. It operates within the framework of a strategic plan aimed at the close integration in a 'Sustainable Supply Chain', SSC, of all the constituents of the SC (such as the producers of the raw materials employed by their key suppliers, or the fish markets). Company A is currently promoting projects aimed at full raw material to consumer SC integration, particularly for the food product range. It leverages sustainability as a holistic strategic approach that supports both cost reduction and process and product quality improvement, thus substantially improving its market competitiveness.

It is apparent from this study that company A sticks out both with regard to the number of supply chain sustainability governance mechanisms it applies (some of which are also used by other companies, while others are not) and to their internal and external characteristics (i.e., how it applies them). Its consequently increasingly integrated and efficient SSCM model might partly explain why company A is outgrowing its competitors and improving its competitiveness. The results of this analysis suggest that the application of the abovementioned supply chain sustainability governance mechanisms within its SSCM model might be instrumental in its accomplishment of achievements such as: (i) boasting the most efficient and less polluting transport model among European companies within its sector, (ii) possessing the most energy-efficient, sustainable stores within Europe, and (iii) attaining the highest customer loyalty for any Spanish chain within its sector. All of which contributes to company A being the fastest growing and most profitable retail company in Spain, besides becoming the absolute leader in the product lines it sells. 


\section{Conclusions}

Supply chain sustainability governance mechanisms are a critical ingredient for the creation of SSCs. This study identified ten representatives of such mechanisms, whose degree of adoption can be used to estimate the maturity level in a company for that key component of the SSC strategy. Some of these mechanisms (I-VIII) derive from the literature review, while others (IX, X, that may be sector-specific or even company-specific) stem from the study itself.

The analysis revealed marked differences in how each firm implements these mechanisms. To enable the in-depth analysis of these differences, besides characterizing the mechanisms through the traits discussed in the literature review, such as direct vs. indirect, their degree of adoption by each company was also characterized through such attributes as formal vs. informal and collaborative vs. non-collaborative. This analysis was carried out at two complementary scope levels or 'views': internal and external. Most of these mechanisms are direct (eight out of ten); only two are deemed indirect: sustainable SC certification and environmental certifications.

Only company A implements all ten mechanisms. Furthermore, not only does it implement them within its own organization, where it has full decision-making power, it also formally extends them to its tier-1 suppliers. It generally cooperates with its suppliers in the implementation of these mechanisms within their SC, except for environmental certifications, which are deemed mandatory. This could be linked to the SC continuous process improvement philosophy that has permeated company A's strategic view since its inception.

Company B has formally implemented in the focal company eight out of these ten mechanisms. However, the external view analysis reveals that only four of them have been implemented by its tier-1 suppliers. Sustainability reports and environmental certifications were formally embraced by its major suppliers; however, local suppliers/sourcing and the waste reduction program were only informally, patchily adopted. No collaborative practices have been identified between company B and its suppliers in the implementation of these four mechanisms.

Six mechanisms have been implemented in the focal company D; all of them formally, except for local suppliers/sourcing, which is largely decided by the individual malls. As for its SC, only two of these supply chain sustainability governance mechanisms have been adopted: environmental certifications, implemented in a formal manner, and the waste reduction program, in an informal manner. No evidence of collaborative practices has been observed.

Company $\mathrm{C}$ has adopted the lowest number of mechanisms; only three. Two of them (sustainable SC certification and environmental certifications) have been formally implemented in the focal company, while local suppliers/sourcing have been informally adopted. Regarding the external analysis, its key suppliers have only adopted environmental certifications, in a formal and non-cooperative manner.

This study indicates that, when analyzing the degree of adoption of supply chain sustainability governance mechanisms, it does not suffice to simply state whether companies adopt, or not, each mechanism. The distinction between the internal and external views, and the characterization of the various adoption traits reveal substantial differences that would otherwise not be identified.

Regarding the potential relationship between the degree of adoption of relevant supply chain sustainability governance mechanisms and the actual attainment of comprehensive SC sustainability (economic, social, environmental), it is worth highlighting how company A stands out on both counts, as discussed in the previous section.

In this respect, the findings of this study suggest that supply chain sustainability governance mechanisms might be classified into two groups. A first type of mechanisms, that could be named 'enablers', would encompass those whose presence, at least to a certain degree, would be deemed almost as a prerequisite for supply chains to achieve appropriate levels of sustainability. They might include, out of the ten analyzed in this paper, the sustainability report, sustainable SC certification, the sustainability committee, the supplier evaluation program, environmental certifications, local suppliers/sourcing and waste reduction programs, as well as any other mechanisms that support the sustainability of the SC, but whose adoption does not, due to its widespread adoption, lead to 
competitive advantages. They have all been observed, in different degrees, in the supply chains of companies A, B and D.

A second, much rarer set of mechanisms could be referred to as 'differentiators'. These mechanisms have been developed by a small number of selected companies, and thus have the potential to bestow a competitive advantage. An example found in this study would be the implementation in company A of a 'sustainability innovation committee', encompassing executives both from the focal company and from the reduced set of suppliers that excel most in sustainability within company A's SC. This company has likewise developed clear strategic SSCM plans that contemplate the long term development of its suppliers; these differentiating 'levers' might confer sustainable strategic advantages.

These 'differentiators' are notably hard to develop (and to replicate), and are seldom found in SCs, even in many self-proclaimed 'Sustainable SCs'. The authors of this study suggest that those leading companies that have successfully implemented a SSCM model aimed at the continuous improvement of its sustainability, such as company A, might actually be developing 'circular improvement models' of their SSCs, akin to those applied in Total Quality Management In these models, supply chain sustainability governance mechanisms might act both as catalysts of improvement and as supporters of the improvements already attained.

It is worth highlighting that, since its inception, company A's strategy has been built around the concept of continuous improvement in all its processes. A quick review of its annual reports/letters to shareholders for the last decade reveals PDCA Deming cycles featuring conspicuously. This might suggest that broader cultural/strategic traits might also either facilitate or hinder the full exploitation of some of these more advanced potential sources of value creation. Being aware of the potential for self-reinforcing continuous improvement in sustainability beyond a certain threshold might, however, enable and/or encourage even less PDCA-prone companies to tap this opportunity.

As discussed before, differentiation would not be achieved solely through the development of these unique 'differentiators'; this should be complemented by a comprehensive strategy of 'deep adoption' of both enabling and differentiating mechanisms in terms of the various traits described, such as internal and external adoption and cooperation.

While comparing these results and conclusions to those reported in recent publications, a relevant aspect is the relationship between mechanism IX, the 'Sustainability innovation committee', and those included among the 'multi-stake holder initiatives' by Koberg and Longoni [39]. This relevancy stems from the key role played by this 9 th mechanism in these conclusions, having been identified as a 'new', previously unreported mechanism, and also as a representative of the 'differentiators' category. In spite of the apparent similarities, a more detailed analysis reveals that they are quite different concepts. Koberg and Longoni identify in this category mechanisms based on a somewhat loose, arms-length relationship with other organizations, academia and the government, involving a certain balance of equality in decision-making. The mechanism termed here as a 'sustainability innovation committee' is specific to a supply-chain and involves a clear dependency relationship, characterized by power and information asymmetries. The study reported in this article could contribute to a better understanding of a research area that Koberg and Longoni consider to be still lagging. Along similar lines, if we consider the so-called Corporate Environmental Sustainability strategies in retailing, our study might also partially fulfill Naido and Gaspavatos' [58] stated need for additional research in this area.

Given the current interest in governance mechanisms applied in an SSCM context, other recent studies also analyze this topic, although from complementary, rather than overlapping, perspectives. Hann-Hoek et al. [63] focused on increasing the involvement of employees, suppliers and visibility in the organization, all within a strict code of conduct. They conceive 'visibility' itself as a control mechanism, since it can help to extend sustainability policies between employees and suppliers. In a similar line of research, authors such as Brun et al. [64] have worked on research that delves into the study of how a mechanism such as the 'development of collaboration with suppliers' can lead to an increase in 'transparency' in the SSCM, through a case study involving a multinational fashion company and a well-known NGO. 
However, to the best of our knowledge, no published research has combined existing theoretical frameworks on the SC sustainability governance mechanisms into an applicable model and then benchmarked it against the actual practices being implemented by the leading companies of an industrial sector (either in Retail or in others), thus resulting into what could be considered as the key contributions of the present article:

- A practicable list of mechanisms, for which both their theoretical basis and supporting literature and their degree of practical application has been established for a key retail sector. This model, including the newly identified mechanisms and their proposed classification into enablers and differentiators, could be used by companies to guide their self-evaluation and improvement plans for SC sustainability governance mechanisms.

- A detailed characterization of their implementation, particularly in terms of their internal and external adoption, thus revealing the need for a comprehensive strategy of 'deep adoption'.

- Initial tentative analysis of the causal relationships between the level of adoption of these mechanisms and the overall SC sustainability level achieved, with the corresponding competitive advantage implications. Particularly relevant is the potential for self-reinforcing continuous improvement in sustainability beyond a certain threshold.

Therefore, companies trying to attain competitive advantages through the sustainability of their SCs should endeavor to both develop differentiating supply chain sustainability governance mechanisms and to attain a consistent level of internal and external implementation of enabling and differentiating mechanisms in order to create a self-sustaining improvement cycle that competitors cannot easily emulate.

The study's limitations include the fact that the current analysis is circumscribed to one country (Spain) and one sector (Food Retail). Additionally, it encompasses only four companies, even though they account for over $40 \%$ of Spain's food retailing. Several promising future research avenues open up to continue this research. An obvious one would be to extend the analysis to other countries and sectors. Building specifically on one of the original contributions of this paper, namely the characterization of the way governance mechanisms are implemented, the authors consider that further work on standardizing approaches to measuring whether a given mechanism is actually effectively implemented in a Supply Chain, and on its characterization, would be particularly useful. Directly related to this point, further developing the mechanism framework presented in this paper, in order to facilitate its utilization by companies in their own self-assessment and improvement roadmaps, could facilitate widespread adoption, particularly of the most advanced mechanisms. One last area, particularly current, would be an analysis of how recent COVID-19 disruptions have affected governance mechanisms, with a focus on their contribution to resilience.

Author Contributions: Conceptualization, J.M.-B. and A.D.-H.; methodology, J.M.-B. and A.D.-H.; formal analysis, J.M.-B. and A.D.-H.; investigation, J.M.-B. and A.D.-H.; writing-original draft preparation, J.M.-B. and A.D.-H.; writing-review and editing, J.M.-B. and A.D.-H.; supervision, J.M.-B. and A.D.-H. All authors have read and agreed to the published version of the manuscript.

Funding: This research received no external funding.

Conflicts of Interest: The authors declare no conflict of interest.

\section{References}

1. Baumgartner, R.J.; Rauter, R. Strategic perspectives of corporate sustainability management to develop a sustainable organization. J. Clean. Prod. 2017, 140, 81-92. [CrossRef]

2. Porter, M.E. What is strategy? Harv. Bus. Rev. 1996, 74, 61-78.

3. Barney, J.B.; Hesterly, W.S. Strategic Management and Competitive Advantage, 4th ed.; Pearson: Boston, MA, USA, 2012.

4. Starik, M.; Rands, G.P. Weaving an integrated web: Multilevel and multisystem perspectives of ecologically sustainable organizations. Acad. Manag. Rev. 2012, 20, 908-935. [CrossRef] 
5. Shrivastava, P. The role of corporations in achieving ecological sustainability. Acad. Manag. Rev. 1995, 20, 936-960. [CrossRef]

6. Carter, C.R.; Rogers, D.S. A framework of sustainable supply chain management: Moving toward new theory. Int. J. Phys. Distrib. Logist. Manag. 2008, 38, 360-387. [CrossRef]

7. Hassini, E.; Surti, C.; Searcy, C. A literature review and a case study of sustainable supply chains with a focus on metrics. Int. J. Prod. Econ. 2012, 140, 69-82. [CrossRef]

8. Rego, A.; Cunha, M.P.; Polónia, D. Corporate sustainability: A view from the top. J. Bus. Ethics 2017, 143, 133-157. [CrossRef]

9. Hahn, T.; Figge, F.; Pinkse, J.; Preuss, L. A Paradox perspective on corporate sustainability: Descriptive, instrumental, and normative aspects. J. Bus. Ethics 2018, 148, 235-248. [CrossRef]

10. Lozano, R. A holistic perspective on corporate sustainability drivers. Corp. Soc. Responsib. Environ. Manag. 2015, 22, 32-44. [CrossRef]

11. Montiel, I. Corporate social responsibility and corporate sustainability: Separate pasts, common futures. Organ. Environ. 2008, 21, 245-269. [CrossRef]

12. Sancha, C.; Gimenez, C.; Sierra, V. Achieving a socially responsible supply chain through assessment and collaboration. J. Clean. Prod. 2016, 112, 1934-1947. [CrossRef]

13. Gimenez, C.; Tachizawa, E.M. Extending sustainability to suppliers: A systematic literature review. Supply Chain Manag. Int. J. 2012, 17, 531-543. [CrossRef]

14. Cooper, M.C.; Lambert, D.M.; Pagh, J.D. Supply chain management: More than a new name for logistics. Int. J. Logist. Manag. 1997, 8, 1-14. [CrossRef]

15. Chopra, S.; Meindl, P. Supply Chain Management. Strategy, Planning \& Operation. In Das Summa Summarum des Management; Gabler: Wiesbaden, Germany, 2007; pp. 265-275.

16. Seuring, S.; Müller, M. From a literature review to a conceptual framework for sustainable supply chain management. J. Clean. Prod. 2008, 16, 1699-1710. [CrossRef]

17. Ashby, A.; Leat, M.; Hudson-Smith, M. Making connections: A review of supply chain management and sustainability literature. Supply Chain Manag. Int. J. 2012, 17, 497-516. [CrossRef]

18. Colicchia, C.; Strozzi, F. Supply chain risk management: A new methodology for a systematic literature review. Supply Chain Manag. Int. J. 2012, 17, 403-418. [CrossRef]

19. Stock, J.R.; Boyer, S.L.; Harmon, T. Research opportunities in supply chain management. J. Acad. Mark. Sci. 2010, 38, 32-41. [CrossRef]

20. Fabbe-Costes, N.; Jahre, M. Supply chain integration improves performance: The Emperor's new suit? Int. J. Phys. Distrib. Logist. Manag. 2007, 37, 835-855. [CrossRef]

21. Pilbeam, C.; Alvarez, G.; Wilson, H. The governance of supply networks: A systematic literature review. Supply Chain Manag. Int. J. 2012, 17, 358-376. [CrossRef]

22. Ahi, P.; Searcy, C. A comparative literature analysis of definitions for green and sustainable supply chain management. J. Clean. Prod. 2013, 52, 329-341. [CrossRef]

23. Vurro, C.; Russo, A.; Perrini, F. Shaping sustainable value chains: Network determinants of supply chain governance models. J. Bus. Ethics 2009, 90, 607-621. [CrossRef]

24. Alvarez, G.; Pilbeam, C.; Wilding, R. Nestlé Nespresso AAA sustainable quality program: An investigation into the governance dynamics in a multi-stakeholder supply chain network. Supply Chain Manag. Int. J. 2010, 15, 165-182. [CrossRef]

25. Vermeulen, W.J.; Seuring, S. Sustainability through the market-the impacts of sustainable supply chain management: Introduction. Sustain. Dev. 2009, 17, 269-273. [CrossRef]

26. Carter, C.R.; Easton, P. Sustainable supply chain management: Evolution and future directions. Int. J. Phys. Distrib. Logist. Manag. 2011, 41, 46-62. [CrossRef]

27. Kovács, G. Corporate environmental responsibility in the supply chain. J. Clean. Prod. 2008, 16, 1571-1578. [CrossRef]

28. Van Bommel, H.W. A conceptual framework for analyzing sustainability strategies in industrial supply networks from an innovation perspective. J. Clean. Prod. 2011, 19, 895-904. [CrossRef]

29. Gawel, E.; Purkus, A.; Pannicke, N.; Hagemann, N. A Governance Framework for a Sustainable Bioeconomy: Insights from the Case of the German Wood-Based Bioeconomy. In Towards a Sustainable Bioeconomy: Principles, Challenges and Perspectives; Springer: Cham, Switzerland, 2018; pp. 517-537. 
30. Petschow, U.; Rosenau, J.; Von Weizsäcker, E.U. Governance and Sustainability: New Challenges for States, Companies and Civil Society; Routledge: Abingdon, UK, 2017.

31. Husted, B.W.; De Sousa-Filho, J.M. The impact of sustainability governance, country stakeholder orientation, and country risk on environmental, social, and governance performance. J. Clean. Prod. 2017, 155, 93-102. [CrossRef]

32. Du Plessis, J.J.; Hargovan, A.; Harris, J. Principles of Contemporary Corporate Governance; Cambridge University Press: Cambridge, UK, 2018.

33. Monks, R.; Minow, N. Corporate Governance; Blackwell Publishing: Malden, UK, 2004; Volume 3.

34. Gimenez, C.; Sierra, V. Sustainable supply chains: Governance mechanisms to greening suppliers. J. Bus. Ethics 2013, 116, 189-203. [CrossRef]

35. Gold, S.; Seuring, S.; Beske, P. Sustainable supply chain management and inter-organizational resources: A literature review. Corp. Soc. Responsib. Environ. Manag. 2010, 17, 230-245. [CrossRef]

36. Hingley, M. Relationship management in the supply chain. Int. J. Logist. Manag. 2001, 12, 57-71. [CrossRef]

37. Formentini, M.; Taticchi, P. Corporate sustainability approaches and governance mechanisms in sustainable supply chain management. J. Clean. Prod. 2016, 112, 1920-1933. [CrossRef]

38. Gualandris, J.; Klassen, R.D.; Vachon, S.; Kalchschmidt, M. Sustainable evaluation and verification in supply chains: Aligning and leveraging accountability to stakeholders. J. Oper. Manag. 2015, 38, 1-13. [CrossRef]

39. Koberg, E.; Longoni, A. A systematic review of sustainable supply chain management in global supply chains. J. Clean. Prod. 2019, 207, 1084-1098. [CrossRef]

40. Jiang, B.; Baker, R.C.; Frazier, G.V. An analysis of job dissatisfaction and turnover to reduce global supply chain risk: Evidence from China. J. Oper. Manag. 2009, 27, 169-184. [CrossRef]

41. Mamic, I. Managing global supply chain: The sports footwear, apparel and retail sectors. J. Bus. Ethics 2005, 59, 81-100. [CrossRef]

42. Busse, C.; Schleper, M.C.; Niu, M.; Wagner, S.M. Supplier development for sustainability: Contextual barriers in global supply chains. Int. J. Phys. Distrib. Logist. Manag. 2016, 46, 442-468. [CrossRef]

43. Liu, X.; Yang, J.; Qu, S.; Wang, L.; Shishime, T.; Bao, C. Sustainable production: Practices and determinant factors of green supply chain management of Chinese companies. Bus. Strategy Environ. 2012, 21, 1-16. [CrossRef]

44. Klassen, R.D.; Vachon, S. Collaboration and evaluation in the supply chain: The impact on plant-level environmental investment. Prod. Oper. Manag. 2003, 12, 336-352. [CrossRef]

45. Gereffi, G.; Humphrey, J.; Sturgeon, T. The governance of global value chains. Rev. Int. Political Econ. 2005, 12, 78-104. [CrossRef]

46. Vellema, S.; van Wijk, J. Partnerships intervening in global food chains: The emergence of co-creation in standard-setting and certification. J. Clean. Prod. 2015, 107, 105-113. [CrossRef]

47. Mueller, M.; Dos Santos, V.G.; Seuring, S. The contribution of environmental and social standards towards ensuring legitimacy in supply chain governance. J. Bus. Ethics 2009, 89, 509-523. [CrossRef]

48. McCutcheon, D.M.; Meredith, J.R. Conducting case study research in operations management. J. Oper. Manag. 1993, 11, 239-256. [CrossRef]

49. Eisenhardt, K.M. Building theories from case research. Acad. Manag. Rev. 1989, 14, 532-550. [CrossRef]

50. Yin, R.K. Case Study Research: Design and Methods; Sage Publications: Beverly Hill, CA, USA, 1994.

51. Smith, E.E.; Perks, S. A perceptual study of the impact of green practice implementation on the business functions. S. Afr. Bus. Rev. 2010, 14, 1-26.

52. Jones, P.; Comfort, D.; Hillier, D. Marketing sustainable consumption within stores: A case study of the UK's leading food retailers. Sustainability 2009, 1, 815-826. [CrossRef]

53. Bradley, P. Environmental impacts of food retail: A framework method and case application. J. Clean. Prod. 2016, 113, 153-166. [CrossRef]

54. Brancoli, P.; Rousta, K.; Bolton, K. Life cycle assessment of supermarket food waste. Resour. Conserv. Recycl. 2017, 118, 39-46. [CrossRef]

55. Cimini, A.; Moresi, M. Effect of Brewery Size on the Main Process Parameters and Cradle-to-Grave Carbon Footprint of Lager Beer. J. Ind. Ecol. 2018, 22, 1139-1155. [CrossRef]

56. Lai, K.H.; Cheng, T.C.E.; Tang, A.K. Green retailing: Factors for success. Calif. Manag. Rev. 2010, 52, 6-31. [CrossRef] 
57. Tang, A.K.; Lai, K.H.; Cheng, T.C.E. A multi-research-method approach to studying environmental sustainability in retail operations. Int. J. Prod. Econ. 2016, 171, 394-404. [CrossRef]

58. Naidoo, M.; Gasparatos, A. Corporate Environmental Sustainability in the retail sector: Drivers, strategies and performance measurement. J. Clean. Prod. 2018, 203, 125-142. [CrossRef]

59. Wang, F.; Zhuo, X.; Niu, B. Sustainability analysis and buy-back coordination in a fashion supply chain with price competition and demand uncertainty. Sustainability 2017, 9, 25. [CrossRef]

60. Fabbri, S.; Olsen, S.I.; Owsianiak, M. Improving environmental performance of post-harvest supply chains of fruits and vegetables in Europe: Potential contribution from ultrasonic humidification. J. Clean. Prod. 2018, 182, 16-26. [CrossRef]

61. De Frias, J.A.; Luo, Y.; Kou, L.; Zhou, B.; Wang, Q. Improving spinach quality and reducing energy costs by retrofitting retail open refrigerated cases with doors. Postharvest Biol. Technol. 2015, 110, 114-120. [CrossRef]

62. Gimeno-Frontera, B.; Mainar-Toledo, M.D.; de Guinoa, A.S.; Zambrana-Vasquez, D.; Zabalza-Bribián, I. Sustainability of non-residential buildings and relevance of main environmental impact contributors' variability. A case study of food retail stores buildings. Renew. Sustain. Energy Rev. 2018, 94, 669-681. [CrossRef]

63. Haan-Hoek, J.; Lambrechts, W.; Semeijn, J.; Caniëls, M.C. Levers of control for supply chain sustainability: Control and governance mechanisms in a cross-boundary setting. Sustainability 2020, 12, 3189. [CrossRef]

64. Brun, A.; Karaosman, H.; Barresi, T. Supply Chain Collaboration for Transparency. Sustainability 2020, 12, 4429. [CrossRef]

(C) 2020 by the authors. Licensee MDPI, Basel, Switzerland. This article is an open access article distributed under the terms and conditions of the Creative Commons Attribution (CC BY) license (http://creativecommons.org/licenses/by/4.0/). 